\title{
ENCAPSULATION OF MANDARIN CITRUS FLAVOR USING SPRAY DRYING TECHNOLOGY AND DIFFERENT WALL MATERIALS
}

\section{ENCAPSULACIÓN DE UN SABOR CÍTRICO DE MANDARINA USANDO TECNOLOGÍA DE SECADO POR ASPERSION Y DIFERENTES MATERIALES DE COBERTURA}

\author{
Jaime A. García-Cárdenas ${ }^{1}$, Héctor J. Ciro-Velásquez*², Esteban Largo-Ávila ${ }^{3}$
}

${ }^{1}$ Chemical Engineer, M.Sc. TECNAS, S.A., e-mail: jcardenas@tecnas.com.co; ${ }^{2}$ Associate Professor, Universidad Nacional de Colombia, Medellín, Colombia, e-mail: hjciro@unal.edu.co; ${ }^{3}$ Agricultural Engineer, M.Sc., e-mail: elargoa@gmail.com *Author for correspondence: hjciro@unal.edu.co

Rev. U.D.CA. Act. \& Div. Cient. 18(1): 251-260, Enero-Junio, 2015

\section{SUMMARY}

Studies using the encapsulated flavors of mandarin oranges have not been reported. In this study, the effect of malto-dextrin, soy protein, gum Arabic and surfactant (polysorbate 80 ) on the emulsion stability of a hydrophobic mandarin flavor for an encapsulation process subsequent to a spray drying process was evaluated. The influence of the emulsion characterization and the drying operating conditions, such as the inlet air temperature, outlet air temperature and atomization speed, on the characteristics of the encapsulated product and dryer performance was considered. The most suitable process was found to be air inlet and outlet temperatures of $213^{\circ} \mathrm{C}$ and $90^{\circ} \mathrm{C}$, respectively, together with an atomizer disk velocity of $35000 \mathrm{rpm}$ to obtain a high encapsulation efficiency of d-limonene and $\alpha$-linalool (>95\%), low deposit formation $(<10 \%)$ and high solids recovery (@ 80\%). Powdered flavors of mandarin orange can be encapsulated by spray drying, resulting in microcapsules containing the active ingredient with maximum functionality and stability.

Key words: Drying, flavor, encapsulation, mandarin.

\section{RESUMEN}

Estudios de encapsulación de sabores artificiales de mandarina no han sido reportados. En este estudio fue avaluado el efecto de maltodextrina, proteína de soja, goma arabiga y un agente de tensioactivo (polisorbato 80), en la estabilidad de una emulsión formulada con sabores artificiales de mandarina, para ser encapsulado mediante secado por aspersión. Usando la metodología de superficie de respuesta, las condiciones de operación del secador (temperatura de entrada y de salida de aire y la velocidad del disco atomizador), se optimizaron en función de las propiedades de calidad del producto en polvo y desempeño del secador. Los resultados mostraron que las temperaturas de entrada y de salida de aire de $213^{\circ} \mathrm{C}$ y $90^{\circ} \mathrm{C}$, respectivamente, junto con una velocidad de disco atomizador de 35000rpm son las más adecuadas para obtener un producto con alta eficiencia de encapsulación de d-limoneno y $\alpha$-linalol (>95\%), baja formación de depósitos (<10\%) y alta recuperación de sólidos (@80\%). Sabores encapsulados de mandarina pueden ser obtenidos mediante secado por aspersión, dando como resultado microcápsulas, que contienen el ingrediente activo con la máxima funcionalidad y estabilidad.

Palabras clave: Secado, sabor, encapsulación, mandarina.

\section{INTRODUCTION}

Among the citrus fruits, the mandarin orange has the useful characteristic of adaptability to different climates, which is a beneficial option for agriculture in Colombia (Espinal et al. 2005; Orduz et al. 2012). Citrus essential oils are composed of different aromatic chemical whose chemical compounds are viewed as great alternatives for flavoring in the chemical and food industries and where one of principal ingredients is d-limonene. The essential oils and d-limonene are liquids in their natural form and have several limitations to be used in the beverages industry. Some authors have reported that these compounds are susceptible to oxidation, through which they lose their flavor characteristics (Kaushik \& Roos, 2007; Marcuzzo et al. 2012). Therefore, the encapsulation of flavors in carrier matrices obtained by spray drying can deliver pure lasting flavors and enrich and fortify foods and beverages without degradation of actives (Aguiar et al. 2012; Jafari et al. 2008). 
The most important aspect for flavor encapsulation by spray drying is flavor retention, which is closely related to the stability and droplet size of emulsions in feed emulsion (Bringas \& Pino, 2012; Soottitantawat et al. 2003). Some studies have reported the encapsulation of d-limonene using spray drying and other technologies (Kaushik \& Roos, 2007; Soottitantawat et al. 2005; Paramita et al. 2010; Marcuzzo et al. 2012).

Studies using the encapsulated flavors of mandarin oranges have not been reported. In this research, the encapsulation process by spray drying of citric artificial flavors of mandarin oranges was considered, using a mixture of maltodextrin, gum arabic and soy protein as wall material and a polysorbate as the emulsifier. The influence of the wall material on the stability of the emulsion and how the operating conditions of spray drying affect the properties of the encapsulated product as well as the performance characteristics of the dryer was evaluated.

\section{MATERIALS AND METHODS}

Emulsion preparation and characterization. The carrier solution or wall material consisted of a mixture of maltodextrin with a dextrose equivalent of 10 , Arabic gum and soy protein using an emulsifier (polysorbate 80). All of the emulsions were prepared as $10 \%$ of the active ingredient (tangerine flavor), $58 \%$ of water and $32 \%$ of a mixture composed of wall materials. An extreme vertices mixture design in the emulsion formulation was applied using surfactant $(0.2-0.8 \%)$, soy protein $(0-1 \%)$, gum arabic $(0-31.8 \%)$ and maltodextrin (0$31.8 \%)$.

The mixture was homogenized for 5 minutes at 10000rpm with a disperser system (Ultra-Turrax IKA-T25) under cooling, keeping the emulsion temperature at $5 \pm 1^{\circ} \mathrm{C}$. The viscosity of the emulsion was measured by a BrookField rheometer DV-III ultra and the droplet size distribution using a laser scattering particle size analyzer (Mastersizer 2000). The droplet size distribution was expressed as a volume distribution defined as the volume/surface diameter ( $\mathrm{D}_{32}$ ) (McClements, 1999; Soottitantawat et al. 2003) The following canonical model-a special cubic model - was used to fit the experimental data (D ${ }_{32}$ and viscosity):

$$
\begin{array}{r}
Y=\sum_{i=1}^{n} \beta_{i} X_{i}+\sum_{i=1}^{n} \quad \sum_{i<j}^{n} \beta_{i j} X_{i} X_{j}+ \\
\sum_{i=1}^{n} \quad \sum_{i<j<k}^{n} \quad \sum_{i=1}^{n} \beta_{i j k} X_{i} X_{j} X_{k}
\end{array}
$$

Where $\mathrm{n}$ is the number of components in the mixture, $\beta_{\mathrm{i}}$ represents the expected response to the pure mixture, $\beta_{\mathrm{ij}}$ and $\beta_{\mathrm{ijk}}$ indicate synergic or antagonistic interaction effects on the response values among the mixture components and $\mathrm{X}$ is the component in the mixture. To find the best emulsion, a numerical optimization was performed with the desirability approach using the Statgraphics software (Statgraphics Centurion $\mathrm{XVI})$, taking the particle size $\left(\mathrm{D}_{32}\right)$ and viscosity as response variables. To validate the emulsion stability at an optimum point, a measurement of the zeta potential was established with a Zetasizer 2000 (Malvern Instruments) at $10,25,40,55$ and 70 minutes.

Spray drying process. The optimized emulsion was subjected to spray drying considering the effect of the operating conditions: inlet air temperature $\left(156-213^{\circ} \mathrm{C}\right)$, outlet air temperature $\left(90-100^{\circ} \mathrm{C}\right)$ and atomization speed (23000-35000rpm). The drying process was carried out using a pilot plant spray dryer with atomizer disk (Vibrasec S.A) with the possibility to control the inlet and outlet air temperature, atomizer disk speed while the mass feed was kept constant. The drying equipment was operated under vacuum pressures and the powder was collected from the cyclone.

The experimental design for the drying process consisted of a compound central design $2^{3}$, with two repetitions at the central point. The following variables of quality of the final product and dryer performance were evaluated: water activity, moisture content, encapsulation efficiency of d-limonene and $\alpha$-linalool, solubility, deposits in the drying chamber, drying rate and solids recovery.

The quantification of d-limonene, $\alpha$-linalool and encapsulation efficiency was performed via chromatography analyses conducted in a GC/MS thermo GC ultra using the methodology given by Jun-xia et al. (2011) and Jafari et al. (2007).

Statistical analysis of the spray drying process. Regression models were evaluated for each response variable and regression parameters were used to interpret which treatment effects were significant $(\alpha=0.05)$. Experimental data were fit to the second-order polynomial model:

$$
Y=\beta_{O}+\sum_{i=1}^{3} \beta_{i} X_{i}+\sum_{i=1}^{3} \beta_{i i} X^{2}{ }_{i}+\sum \sum_{i<j=1}^{3} \beta_{i j} X_{i} X_{j}
$$

Where $\beta_{0}, \beta_{\mathrm{i}}, \beta_{\mathrm{ii}}$, and $\beta_{\mathrm{ij}}$ are the regression coefficients for intercept, linear, quadratic and interaction terms, respectively, and $X_{\mathrm{i}}$, and $\mathrm{X}_{\mathrm{j}}$ are the independent variables. The Statgraphics software (Statgraphics Centurion XVI) was used to generate response surfaces and contour plots.

Optimization of the spray drying process. To obtain good microencapsulation efficiency, optimal spray drying conditions are required, even if the wall material is suitable. The operating conditions of the spray dryer (inlet and outlet air temperature and atomizer disk speed) were optimized 
according to dryer performance and the quality of the final product using the response surface methodology (Abano et al. 2014; Singh et al. 2012). Likewise, studies of thermal analysis (glass transition temperature) and morphological characterization of the powder were established at the optimal point.

Morphological characterization by scanning electron microscopy (SEM). The external and internal structures of the encapsulated powder were studied by SEM. The powder was placed on the SEM stubs using two-sided adhesive tape (Nisshin EM, Tokyo, Japan) and then analyzed at 15 $\mathrm{kV}$ acceleration voltages after Pt-Pd sputtering by a MSP-1S magnetron sputter coater.

Thermal analysis. The glass temperature for the encapsulated mandarin powder was evaluated employing the DSC technique. All experiments were carried out using a differential scanning calorimeter (Q200-TA instruments) under dynamic nitrogen, with a flow rate of $50 \mathrm{~mL} / \mathrm{min}$ (pressure of $1 \mathrm{~atm})$, a modulated heating rate of $2^{\circ} \mathrm{C} / \mathrm{min}(40-$ $200^{\circ} \mathrm{C}$ temperature range) per run and an oscillation period of $60 \mathrm{~s}$. This determination was performed in duplicate.

\section{RESULTS AND DISCUSSION}

Emulsion viscosity and particle size. The values of particle size ranged from 0.6 to $2.7 \mu \mathrm{m}$ for $\mathrm{D}_{32}$ (data not shown). According to the results (particle size), it can be concluded that, in general, all of the emulsions are stable (Soottitantawa et al. 2005; Paramita et al. 2010; Tonon et al. 2011). In the microencapsulation of limonene, Paramita et al. (2010) found that the most stable emulsion was prepared by combinations of Arabic gum, maltodextrin and an emulsifier agent, where the particle mean size ranged from 1.41 to $3.43 \mu \mathrm{m}$. Soottitantawa et al. (2005) microencapsulated d-limonene using a mixture of Arabic gum and maltodextrin and found that the particle size of the emulsions varied from 0.84 to $3.37 \mu \mathrm{m}$. These results are similar to the values found in this study.

The rheological characterization shows that the behavior of all emulsions was Newtonian and the viscosity ranged from 31 to $865 \mathrm{mPa}$.s, where the fitted models show a high regression coefficients for linear relationships $\left(R^{2}=0.99\right)$. This Newtonian behavior is typical in stabilized acacia gum emulsions in which the hydrophobic flavor dispersed particles behave as spheres and are not significantly affected by Brownian motion due to the viscosity of the continuous phase (Given, 2009). In studies that involve an emulsion, the viscosity of the emulsion to be dried is an important performance parameter. In a highly viscous liquid, the diffusivity of the flavor molecule decreases and the circulation flow inside the sprayed droplet ceases. However, a high viscosity negatively affects the droplet formation in the atomization device. Paramita et al. (2010) recommend viscosity values of approximately $300 \mathrm{mPa}$.s to obtain a stable emulsion with an appropriate droplet formation.

The ANOVA $(\alpha=0.05)$ for the model defined by Eq. 1 , indicated a statistically significant difference $(p<0.05)$ for viscosity in relation to the factors $\mathrm{A}, \mathrm{B}, \mathrm{C}$ and $\mathrm{D}$ but not their interactions ( $p>0.05)$. Additionally, the statistical analysis of the particle mean size $\left(D_{32}\right)$ did not show a significant difference ( $>0.05)$ for the individual effects and their interactions. The $D_{32}$ value varied from 0.6 to $2.7 \mu \mathrm{m}$ and these values are similar to those reported by Soottitantawat et al. (2005) when using 1:1 mixtures of maltodextrin and gum arabic to encapsulate d-limonene. The special cubic model showed a low determination coefficient $\left(R^{2}<0.5\right)$ together with the $\beta_{\mathrm{ijk}}$ coefficients without significant statistical effect. Hence, the quadratic model (mixture design) was used, which presented a higher determination coefficient $R^{2}>0.7$ with a lack of fit without a statistical effect $(p>0.05)$.

According to the coefficients of the quadratic model (Eq.1), for the mixture design in the emulsion viscosity for the range of concentrations studied, the quantity of surfactant increases the viscosity $\left(\beta_{A}>0\right)$ and the soy protein decreases it $\left(\beta_{B}<0\right)$. The concentration of the surfactant in the range studied strongly affects the viscosity of the emulsion. This fact is especially important when there are interactions with fat. In this study, the flavor compounds are completely hydrophobic and non-polar and can be considered to be acting as fats. This explains the similitude in the behavior between these types of emulsions. Arancibia et al. (2011) found that the fat content together with an emulsifier tends to increases the viscosity of the emulsions, which is the situation obtained in this study.

The gum arabic and maltodextrin concentration increases the viscosity of the emulsion but in a lower proportion $\left(\beta_{\mathrm{d}}<\right.$ $\left.\beta_{c}<\beta_{A}\right)$. The results obtained in this study are comparable to Gharsallaoui et al. (2007), who reported that maltodextrin and gum arabic are excellent for microencapsulation applications due to their relative low viscosity at high concentrations, allowing the emulsion to obtain good stability properties.

Optimization process of the emulsion. This process was performed considering only the emulsion viscosity because the particle mean size did not show a statistically significant difference ( $p>0.05)$. The drying equipment used in this study was designed to work with suspensions having a viscosity lower than $300 \mathrm{mPa}$.s. The results of the optimization process and its experimental validation showed a viscosity value of $180 \mathrm{mPa}$.s, which is approximately $10 \%$ lower than the value predicted by the model $(200 \mathrm{mPa} . \mathrm{s})$. Thus, the following optimal formulation was found: maltodextrin (15.9\%), Arabic gum (15.9\%) and surfactant (0.2\%). 
To validate the stability of the emulsion found by the optimization analysis, its zeta potential was assessed at different times (10, 25, 40, 55 and 70 min). A mean value of the zeta potential of $-32.83 \mathrm{mV}$ was obtained, with no time dependence. Therefore, it can be concluded that this emulsion has good properties for a microencapsulation process by spray drying. Also, the net charge in the diffuse phase of the particles in the emulsion is negative; this type of charge is provided by the Arabic gum, which is a negatively polyelectrolyte polymer (Jun-xia et al. 2011).

Spray drying process and characterization of the final product. Tables 1 and 2 show the degree of variation for the characteristics of quality of the powder and dryer performance.

Table 1 indicates the moisture content values ranged from 1.82 to $3.42 \%$ w.b without a statistical effect of drying operation conditions $(p>0.05)$. These results are similar to the values found for the Jaboticaba powder reported by Paramita et al. (2010) using spray drying with inlet temperatures above $180^{\circ} \mathrm{C}$. Silva et al. (2013) reported that if the drying temperature is sufficiently high, then the final moisture of the finished product is closer to the monolayer moisture.

Guzmán \& Castaño (2002) reported that the final moisture content is also influenced by the atomizer speed and the emulsion composition (the composition was kept constant). If the atomization speed is faster, then the drop size is lower and therefore the moisture content of the finished product is lower. However, when the atomizer disk speed is above the minimum atomization linear speed $\left(120 \mathrm{~ms}^{-1}\right)$, then independent droplets are produced and the moisture is not affected by this velocity. In this study, all linear velocities of the atomizer disk were above the minimum speed and hence there was no effect of speed on the powder's final moisture.

The encapsulation efficiency for both d-limonene and $\alpha$-linalool did not show a significant difference $(p>0.05)$ with regard to the factors in the ranges studied (Table 1). Many authors have reported that the encapsulation efficiency for hydrophobic components is influenced by the preparation of the emulsion and its particle size (Soottitantawat et al. 2003; Soottitantawat et al. 2005; Gharsallaoui et al. 2007; Paramita et al. 2010; Bringas \& Pino, 2012). In this study, all of the emulsions did not show an effect of particle size and the manufacturing process was conducted as previously described so that the encapsulation efficiency did not show statistically significant differences.

The inlet air temperature does not have a statistical effect $(p>0.05)$ on the encapsulation efficiency. This behavior was explained by Bringas \& Pino (2012), who reported that the range of temperatures for drying volatile components should be from 160 to $210^{\circ} \mathrm{C}$. The temperatures defined in this work were $156-220^{\circ} \mathrm{C}$. Reineccius (2006) indicated that the low volatility presented in the citrus flavors does not affect the drying temperatures and is unimportant in the microencapsulation process of these types of products. Additionally, table 1 show that the solubility of the encapsulated tangerine flavor did not show a statistical effect with the drying operating conditions ( $>>0.05$ ) where the powder obtained is highly soluble (>99\%). This behavior can be explained by the presence of maltodextrin and Arabic gum, which are very soluble in water (Phillips \& Willians, 2000).

The surface responses to dryer performance characteristics according to the drying operating conditions shows in figure 1. In general, for higher atomization speeds, the formation of deposits in the drying chamber tends to decrease (Figure 1: A3). This fact is associated with the formation of smaller drops that are more easily dried (Gharsallaoui et al. 2007). Additionally, it was found that the adhesion of solids increases when the inlet air temperature is increased and the outlet air temperature diminishes (Figure 1: A1, A2 and A3).

The increase of the solid adhesion in the drying chamber with an increase of inlet air temperature is due to the dry solid undergoing a phase transition of the first order (melting process), promoting the adhesion of other dry particles (Roos, 1995). Moreover, the increase in the outlet air temperature reduces the formation of deposits because the drying time is shorter and consequently the number of moist particles impacting the wall of the chamber is decreased (Guzmán \& Castaño, 2002).

Figure 1 (B1, B2 and B3) shows that increasing the atomization speed slightly affects the evaporation rate of water. The statistical analysis indicated that the evaporation rate is influence positively by the inlet temperature and negatively by the outlet temperature over the range studied. Thus, the evaporation rate is high when the temperature differences of air drying tend to increase, which increases water evaporation. According to Goula \& Adamopoulos (2010), it is desirable to have a high evaporation rates; therefore, it is necessary to set low outlet temperatures and high inlet temperatures, but this combination of temperatures is limited by the volume of the spray dryer. However, a high air inlet temperature causes excessive evaporation and results in membrane cracks, inducing the subsequent premature release, degradation of the encapsulated ingredient and loss of volatiles (Silva et al. 2013). Additionally, figure 1 (B1, B2 and B3) indicates that the atomization speed negatively affects the evaporation rate where increasing the atomization speed accelerates the exit of the drops from the atomizer disk, producing an impact of the particles on the dryer wall without removing enough water, which decreases its evaporation and increases the adhesion of particles on the drying chamber (Gharsallaoui et al. 2007). 


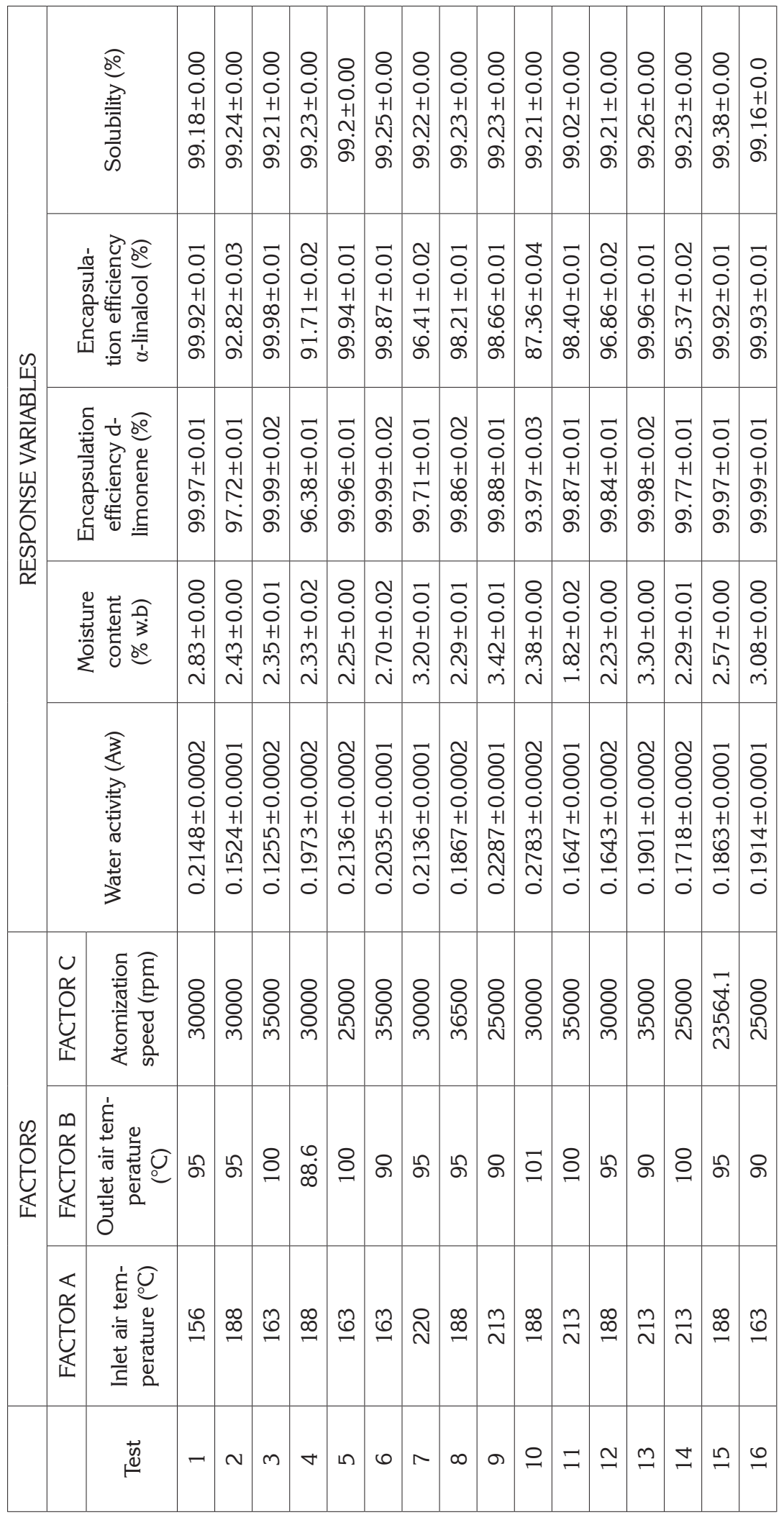


Table 2. Experimental results of the spray dryer performance.

\begin{tabular}{|c|c|c|c|c|c|c|}
\hline \multirow{3}{*}{ Test } & \multicolumn{3}{|c|}{ Statistical effects } & \multicolumn{3}{|c|}{ RESPONSE VARIABLES } \\
\hline & FACTOR A & FACTOR B & FACTOR C & \multirow[b]{2}{*}{$\begin{array}{c}\text { Solids recov- } \\
\text { ery (\%) }\end{array}$} & \multirow[b]{2}{*}{$\begin{array}{l}\text { Deposits in the } \\
\text { drying chamber } \\
(\%)\end{array}$} & \multirow[b]{2}{*}{$\begin{array}{c}\text { Evaporation } \\
\text { rate }(\mathrm{kg} / \mathrm{h})\end{array}$} \\
\hline & $\begin{array}{l}\text { Inlet air tem- } \\
\text { perature }\left({ }^{\circ} \mathrm{C}\right)\end{array}$ & $\begin{array}{l}\text { Outlet air tem- } \\
\text { perature }\left({ }^{\circ} \mathrm{C}\right)\end{array}$ & $\begin{array}{l}\text { Atomization } \\
\text { speed (rpm) }\end{array}$ & & & \\
\hline 1 & 156 & 95 & 30000 & 84 & 8 & 0.77 \\
\hline 2 & 188 & 95 & 30000 & 81 & 18 & 1.43 \\
\hline 3 & 163 & 100 & 35000 & 52 & 16 & 1.17 \\
\hline 4 & 188 & 89 & 30000 & 79 & 18 & 1.68 \\
\hline 5 & 163 & 100 & 25000 & 76 & 12 & 1.01 \\
\hline 6 & 163 & 90 & 35000 & 72 & 17 & 1.03 \\
\hline 7 & 220 & 95 & 30000 & 70 & 18 & 2.31 \\
\hline 8 & 188 & 95 & 36500 & 83 & 13 & 1.19 \\
\hline 9 & 213 & 90 & 25000 & 58 & 21 & 2.98 \\
\hline 10 & 188 & 101 & 30000 & 84 & 15 & 1.05 \\
\hline 11 & 213 & 100 & 35000 & 79 & 16 & 1.49 \\
\hline 12 & 188 & 95 & 30000 & 78 & 21 & 1.22 \\
\hline 13 & 213 & 90 & 35000 & 79 & 11 & 2.17 \\
\hline 14 & 213 & 100 & 25000 & 79 & 28 & 1.66 \\
\hline 15 & 188 & 95 & 23500 & 74 & 19 & 1.49 \\
\hline 16 & 163 & 90 & 25000 & 94 & 20 & 0.96 \\
\hline
\end{tabular}

The solid recovery is complementary to the formation of deposits in the chamber; consequently, a decrease in solid recovery produces greater formation of solid deposits in the drying chamber. According to figure 1 ( $\mathrm{C} 1, \mathrm{C} 2$ and $\mathrm{C} 3$ ), the atomization disk speed has an important effect on the solid recovery. At atomization speed about 36000rpm, the recovery of solids is lower compared to the atomization velocities at 23000 and 30000rpm because the drops travel faster and tend to impact the walls while they are wet, causing adhesion to the chamber and cohesion with other particles (Solval et al. 2012).

Additionally, figure 1 ( $11, \mathrm{C} 2$ and $\mathrm{C} 3$ ) indicated that increasing the inlet air temperature reduced the solids recovery. Increasing the inlet air temperature often causes the melting of powder and cohesion wall so the amount of powder production and solids recovery is reduced.

Optimization of the drying process. The optimization of the drying process was performed by maximizing the evaporation rate and the solid recovery, whereas the deposit in the drying chamber was minimized (Table 2). The other variables were set in the ranges initially defined. The following results of the operating conditions were found: inlet temperature of $213^{\circ} \mathrm{C}$, outlet temperature of $90^{\circ} \mathrm{C}$ and atomization disk speed of 35000rpm. The results indicated that the optimized statistical model tends to underestimate the solid recovery (13\%) and overestimate the deposits in the drying chamber (21\%). Moreover, considering the evaporation rate, the results of the experimental and predicted values are similar and close to the working evaporation capacity of the spray dryer (differences less than 5\%).

Morphological characterization by scanning electron microscopy (SEM). At the optimal drying conditions, the internal and external structure of the microcapsules was evaluated using SEM. Figure 2 shows nearly complete spheroids; there practically is no evidence of broken microcapsules. This characteristic is indicative of the good structure of the microcapsules found in the final product (powder). Additionally, at the surface, there is no presence of porous surfaces; it is completely smooth. This fact is very important for the shelf life of the product because porous surfaces tends to lose volatiles easily over time and permits the permeability of oxygen into the microcapsule, causing undesirable reactions with the core.

Thermal analysis (DSC): The results of the DSC analysis (Figure 3) exhibited an endothermic peak at $170^{\circ} \mathrm{C}$ that 


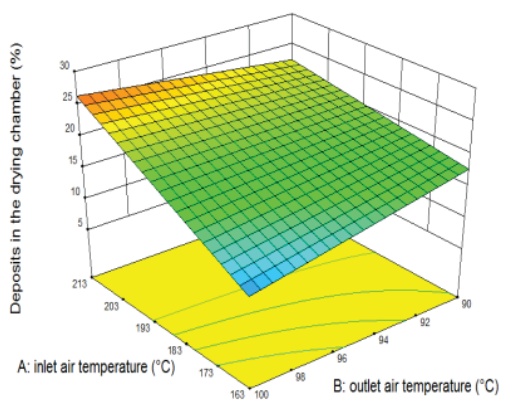

A1

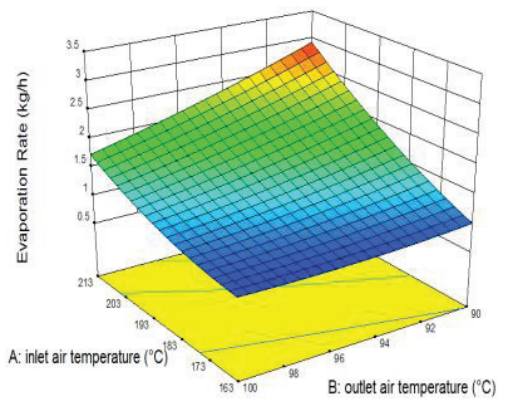

B1

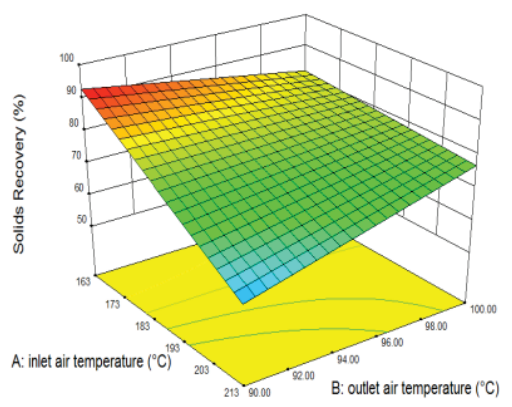

C1

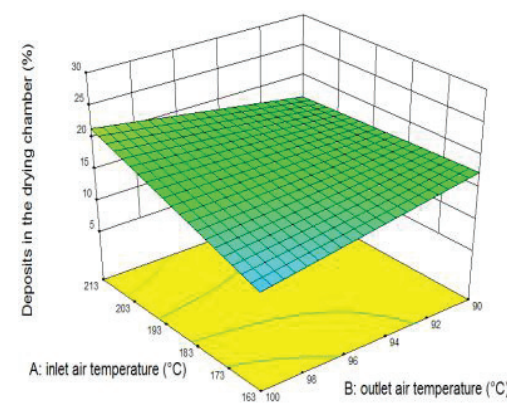

A2

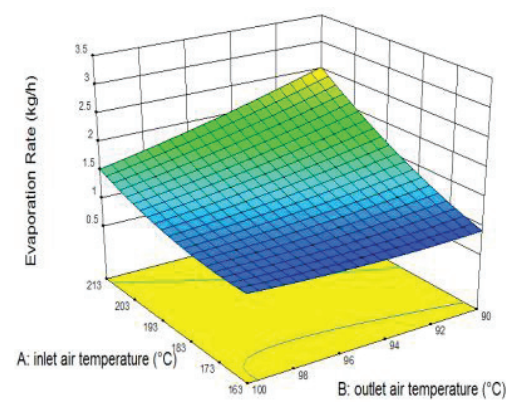

B2

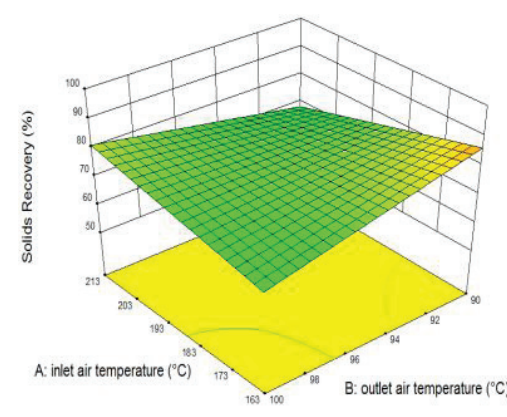

C2

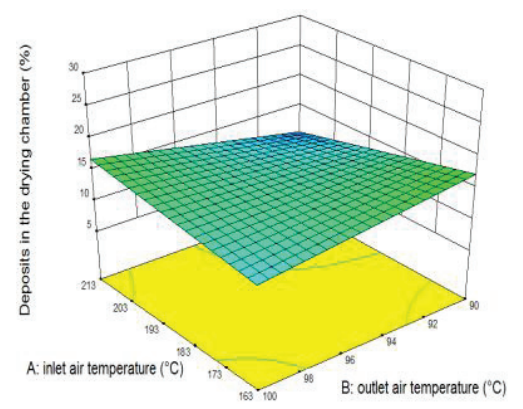

A3

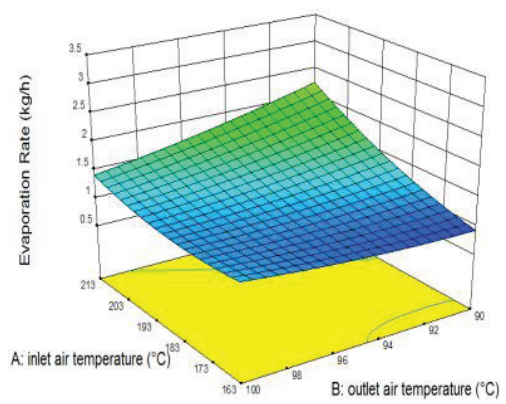

B3

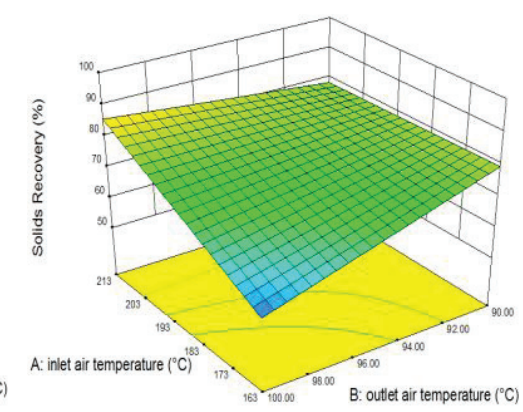

C3

Figure 1. Dryer performance: deposits in the drying chamber (A), evaporation rate (B), and solid recovery (C). The numbers 1,2 and 3 represent the low axial point (23540rpm), central point (30000rpm) and high axial point (36500rpm), respectively.

corresponds to the melting point, with an enthalpy of $72.31 \mathrm{~kJ} / \mathrm{kg}$. Additionally, the glass transition temperature was approximately $95.34^{\circ} \mathrm{C}$, with an onset at $88.56^{\circ} \mathrm{C}$ and an endpoint at $104.86^{\circ} \mathrm{C}$. Maltodextrin and gum arabic are the two main ingredients of the encapsulated flavor, and their glass transition temperatures are $162^{\circ} \mathrm{C}$ and $280^{\circ} \mathrm{C}$, respectively (Mothé \& Rao, 2000; Kurozawa et al. 2009). The decrease in $\mathrm{Tg}$ for the encapsulated product is due to incorporating low molecular weight components within the product, such as the flavor core (Kurozawa et al. 2009).
The glass transition temperature $(\mathrm{Tg})$ obtained for the encapsulated product $\left(95.34^{\circ} \mathrm{C}\right)$ guarantees its stability during storage (maximum temperature of $35^{\circ} \mathrm{C}$ ) and the spray drying process (optimum temperature of $90^{\circ} \mathrm{C}$ for the process). This stability is due to the quantifiable sticky behavior of an amorphous product observed at temperatures approximately $20^{\circ} \mathrm{C}$ above $\mathrm{Tg}$ (Fang \& Bhandari, 2012). This means that the encapsulated product will not exhibit sticky characteristics at temperatures under $110^{\circ} \mathrm{C}$. During the spray drying process, the normal outlet air temperatures 

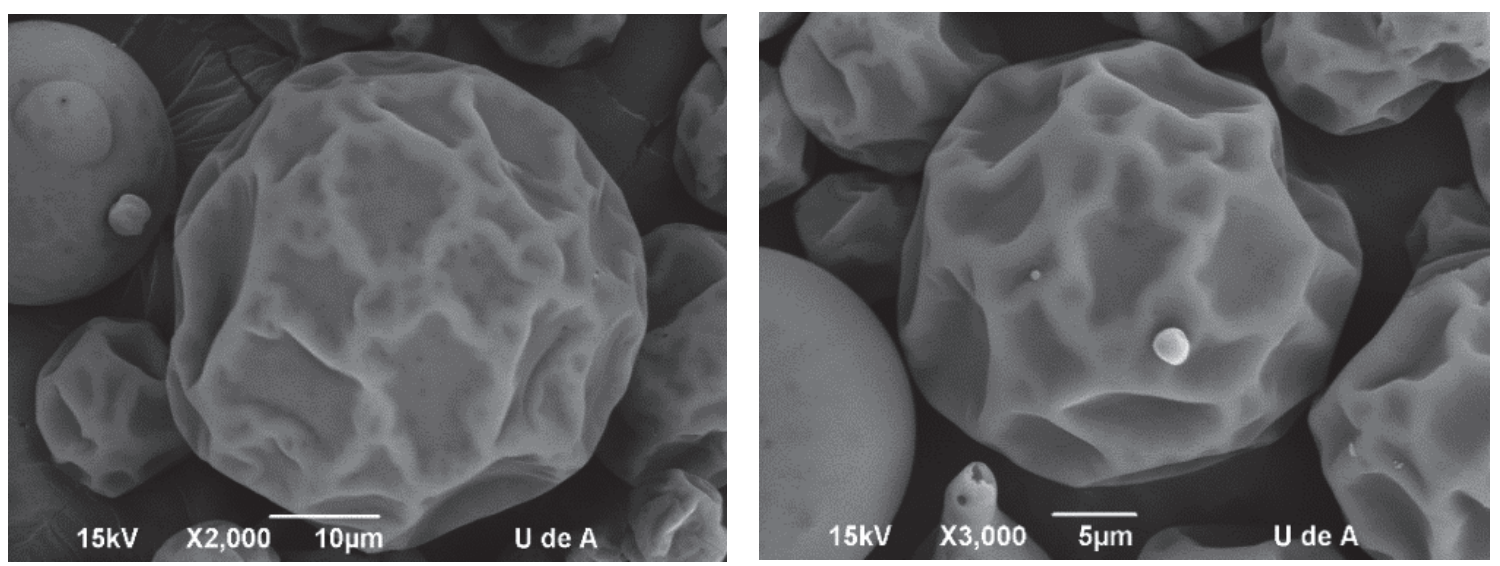

Figure 2. Scanning electron microscopy (SEM) of the encapsulated powder.

range from 60 to $100^{\circ} \mathrm{C}$. Therefore, under these drying conditions, the typical surface temperature of a particle is $40-50^{\circ} \mathrm{C}$; therefore, if the $\mathrm{Tg}$ of the product is less than $38^{\circ} \mathrm{C}$, it will be sticky (Masters, 1991). This observation explains the high solid recovery obtained under the optimal drying conditions (90.4\%).

The use of encapsulated flavors for controlled-release applications is a promising alternative for the food industry, where the challenges are to select the appropriate encapsulation technique and encapsulating material. Powdered flavors of mandarin orange can be encapsulated by spray drying, resulting in microcapsules containing the active ingredient with maximum functionality and stability. The properties of the wall and core materials, the emulsion characteristics and the drying parameters are the factors that can affect the encapsulation process. The in feed emulsion characteristics play an important role in the retention and stability of mandarin orange flavors.

Acknowledgements: The authors wish to thank TECNAS S.A. (Medellín-Colombia) for the full financing of this research, including a grant for the M.Sc. student involved in this work. Conflict of interest: This paper was prepared with the participation of all the authors, who declare that no conflict of interest that threatens the validity of the results presented.

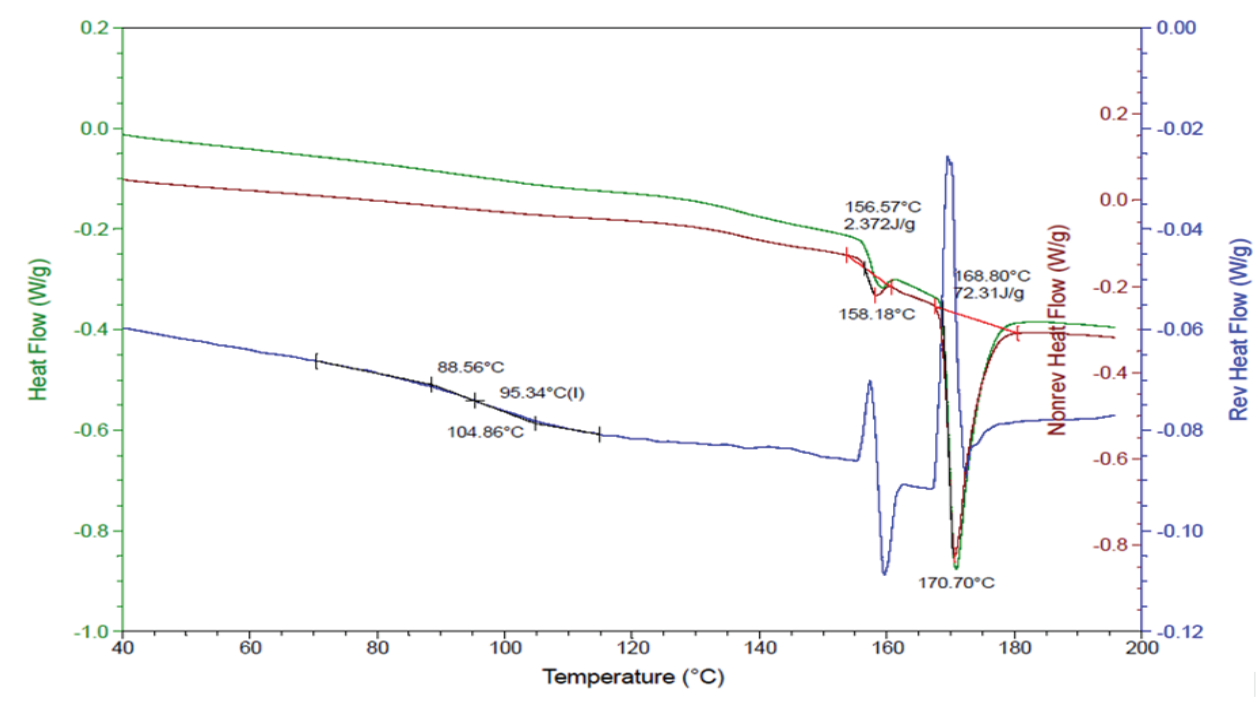

Figure 3. Thermal analysis (DSC) for the encapsulated flavor. 


\section{BIBLIOGRAPHY}

1. ABANO, E.E.; MA, H.; QU, W. 2014. Optimization of drying conditions for quality dried tomato slices using response surface methodology. J. Food Process. Preserv. 38(3):996-1009.

2. AGUIAR, G.; FÁVARO, C.; RAIMUNDO, C. 2012. Microencapsulation of lycopene by spray drying: Characterization, stability and application of microcapsules. Food Bioprod. Process. 90(1):37-42.

3. ARANCIBIA, C.; JUBLOT, L.; COSTELL, E.; BAYARRI, S. 2011. Flavor release and sensory characteristics of $\mathrm{o} / \mathrm{w}$ emulsions. Influence of composition, microstructure and rheological behavior. Food Res. Int. 44(6):1632-1641.

4. BRINGAS, M.; PINO, J. 2012. Microencapsulación de saborizantes mediante secado por atomización. ReCiTeIA. 11(2):34-68.

5. ESPINAL, C.; MARTINEZ, H.; PEÑA, Y. 2005. La cadena de cítricos en Colombia, una mirada global de su estructura y dinámica 1991-2005. Documento de trabajo \# 66:59p Ministerio de Agricultura y Desarrollo Rural Observatorio Agrocadenas Colombia. Disponible desde Internet en: http:// www.asohofrucol.com.co/archivos/Cadenas/ caracterizacion_citricos_2005.pdf (con acceso 24 de Mayo 2014).

6. FANG, Z.; BHANDARI, B. 2012. Comparing the efficiency of protein and maltodextrin on spray drying of bayberry juice. Food Res. Int. 48(2):478-483.

7. GHARSALLAOUI, G.; ROUDAUT, G.; CHAMBIN, O.; VOILLEY, R.; SAUREL, R. 2007. Review Applications of spray-drying in microencapsulation of food ingredients: An overview. Food Res. Int. 40(9):11071121.

8. GIVEN, P. 2009. Encapsulation of Flavors in Emulsions for Beverages. Colloid \& Interface Sci. 14(1):43-47.

9. GOULA, A.; ADAMOPOULOS, K. 2010. A new technique for spray drying orange juice concentrate. Innovative Food Sci. and Emerging Tech. 11(2):342-351.

10. GUZMÁN, G.; CASTAÑO, J. 2002. Secado por atomización del jugo de la caña de azúcar. Rev. Cenicafé. 53(4):327-333.
11. JAFARI, S.M.; HE, Y.; BHANDARI, B. 2007. Encapsulation of nanoparticles of $d$-limonene by spray drying: role of emulsifiers and emulsifying techniques. Drying Tech. 25:1079-1089.

12. JAFARI, S. M., ASSADPOOR, E., HE, Y.; BHANDARI, B. 2008. Encapsulation efficiency of food flavours and oils during spray drying. Drying Tech. 26:816-835.

13. JUN-XIA, X.; HAI-YAN, Y.; JIAN, Y. 2011. Microencapsulation of sweet orange oil by complex coacervation with soybean protein isolate/gum Arabic. Food Chem. 125(4):1267-1272.

14. KAUSHIK, V.; ROOS, Y. 2007. Limonene encapsulation in freeze-drying of gum Arabic-sucrose-gelatin systems. LWT - Food Sci. and Tech. 40(8):1381-1391.

15. KUROZAWA, L., PARK, K.; HUBINGER, M. 2009. Effect of maltodextrin and gum arabic on water sorption and glass transition temperature of spray dried chicken meat hydrolysate protein. J. Food Eng. 91(2):287296.

16. MARCUZZO, E., DEBEAUIFORT, F., SENSIDONI, A., TAT, L., BENEY, L., HAMBLETON, A., PERESSINI, D., VOILLEY, A. 2012. Release behavior and stability of encapsulated D-limonene from emulsion-based edible films. J. Agric. Food Chem. 60(49):1217712185

17. MASTERS, K. 1991. The spray drying handbook. Longman Scientific and Technical, New York, USA. 725p.

18. MCCLEMENTS, D. 1999. Food Emulsions: Principles, Practice and Techniques. CRC Press. Boca Raton, Florida, USA. 378p.

19. MOTHÉ, C.; RAO, M. 2000. Thermal behavior of gum arabic in comparison with cashew gum. Thermochimica Acta. 357-358:9-13.

20. ORDUZ, J.; MONROY, J.; BARRERA, S.; NUÑEZ, V.; LIGARRETO, G. 2012. Caracterización morfoagronómica y molecular de mandarina 'Arrayana' en el piedemonte del Meta (Colombia). Rev. Corpoica Ciencia y Tecn. Agrop. 13(1):5-12.

21. PARAMITA, V.; FURUTA, T.; YOSHIIA, H. 2010. Microencapsulation efficacy of $d$-Limonene by spray drying using various combinations of wall materials and emulsifiers. Food Sci. Tech. Res. 16 (5):365372. 
22. PHILLIPS, G.; WILLIANS, P.2000. Handbook of hydrocolloids. Woodhead Publishing Limited, Cambridge, England. 450p

23. REINECCIUS, G. 2006. Flavor chemistry and technology. Second edition. CRC Press Taylor and Francis Group. Boca Raton, Florida, USA. 489p.

24. ROOS, Y. 1995. Phase Transitions in Foods. Academic Press, New York, CA, USA. 360p.

25. SILVA, P.; STRINGHETA, P.; TEÓFILO, R.; REBOUÇAS, I. 2013. Parameter optimization for spray-drying microencapsulation of jaboticaba (Myrciaria jaboticaba) peel extracts using simultaneous analysis of responses. J. Food Eng. 17(4):538-544.

26. SINGH, B., YADAV, R.B.; JATAIN, M. 2012. Optimization of osmotic dehydration conditions of peach slices in sucrose solution using response surface methodology. J. Food Sci. Tech. 49(5):547-555

27. SOLVAL, K.; SUINDARARAJAN, S.; ALFARO, L.; SATHIVEL, S. 2012. Development of cantaloupe
(Cucumis melo) juice powders using spray drying technology. LWT - Food Sci. Tech. 46(1):287-293.

28. SOOTTITANTAWAT, A.; YOSHII, H.; FURUTA, T.; OHGAWARA, M.; LINKO, P. 2003. Microencapsulation by spray drying: Influence of emulsion size on the retention of volatile compounds. J. Food Sci. 68(7):2256-2262.

29. SOOTTITANTAWAT, A.; BIGEARDB, F.; YOSHIIA, H.; FURUTA, T.; OHKAWARA, M.; LINKOD, P. 2005. Influence of emulsion and powder size on the stability of encapsulated d-limonene by spray drying. Innovative Food Sci. Emerging Tech. 6(1):107-114.

30. TONON, R., GROSSO, C.; HUBINGER, M. 2011. Influence of emulsion composition and inlet air temperature on the microencapsulation of flaxseed oil by spray drying. Food Res. Int. 44(1):282-289.

Received: 22 October 2014

Accepted: 22 February 2015

How to cite (Cómo citar):

García-Cárdenas, J.A.; Ciro-Velásquez, H.J.; Largo-Ávila, E. 2015. Encapsulation of mandarin citrus flavor using spray drying technology and different wall materials. Rev. U.D.C.A Act. \& Div. Cient. 18(1): 251-260. 